Mothers' business, work/life and the politics of 'mumpreneurship'

Carol Ekinsmyth *

Department of Geography, Buckingham Building, Lion Terrace, University of Portsmouth, Portsmouth, Hampshire. PO1 3HE. United Kingdom.

*Email: carol.ekinsmyth@port.ac.uk

WC: 9769 (no figs)

$\mathrm{CN}=$ Yes

Ackn $=$ Yes 


\title{
Mothers' business, work/life and the politics of 'mumpreneurship'
}

\section{Carol Ekinsmyth*}

\begin{abstract}
Heralded by some as 'the new feminism', the new, internationally widespread phenomenon of 'the mumpreneur' represents a hotly contested and contestable subject identity. This article explores the debate, arguing that its themes drive to the heart of current issues regarding changing working practices, locations and gender-identities in affluent societies. The analyses of women entrepreneurs' views presented here $(n=330)$, reveals that practitioners are sharply polarized on 'the mumpreneur'. This article explores these views and progresses research agendas by asking whether such ICTenabled transformations in working practices (embodied in the figure of the 'mumpreneur') have the potential to deliver greater choice for mothers' labour, or whether, conversely, they re-enable iniquitous gender role expectations and arrangements within families.
\end{abstract}

Keywords: Mumpreneur, motherhood, gender, work, entrepreneurship, family

Women's business ownership varies in economic significance around the globe (Global Entrepreneurship Monitor (GEM) Women's Report 2010). It is recognised by Governments as a key growth sector and has gained additional import (and momentum) in the current period of global economic recession. 'Women's business' however, is a crude label masking considerable variability (globally, socially and operationally). One new form/practice, where mothers (as distinct from women generally), configure businesses around their motherhood role, is worthy of separate attention. Here, business and motherhood are co-constituted, their spatialities newly enabled by ICTs. These businesses are not merely (or even necessarily) located in the home, but, creatively use the home, mother-role and child-oriented neighbourhood space(s) to do business (Ekinsmyth 2011). This might be conceived as 'familyto-business enrichment', a situation where the home and work are 'allies' rather than in conflict (Powell and Eddleston, 2013, 261). This significant phenomenon represents the blurring of boundaries between home and work and the co-construction of gendered identities.

This business figure has recently attracted the label 'Mum/Mompreneur' in some countries. Originating (circa 2005) in the practitioner blogosphere, it has been promoted by businesswomen who have built businesses around the provision of networking and support opportunities for this 'group' ${ }^{1}$. Its naming is significant because without a label, it is not 
possible to distinguish and discuss this form of entrepreneurship. And I contend here that it does need separate consideration. For these reasons, the label is increasingly filtering into media, academic, business, and policy discourse.

There is concern, however, that the activity and its actors are negatively affected by its naming. Having arisen organically, there is unease and uncertainty about who qualifies as a 'mumpreneur', and whether the ascription of 'mother' or even gender to a business identity is helpful. On the basis of empirical research, this article will a) identify the dimensions of 'mumpreneurship' and b) consider its discursive construction. This is in order to demonstrate the widespread relevance of this new type of entrepreneur (whether named 'mumpreneur' or not) for mothers' labour politics, and provide a more comprehensive and nuanced definition than hither too exists. It will discuss the view that the growing 'mumpreneur' phenomenon has the potential to disrupt hegemonic dualisms that position 'mother' as antithetical to 'good worker'. This is my contention here, though this view is contested.

Women's business start-ups are growing in many advanced capitalist nations, though they vary considerably in proportion to men's' around the globe (GEM Women's Report (2010)). In advanced market economies, women own 25\% of all businesses (approximately $40 \%$ in the USA) and elsewhere, the proportion of women-owned businesses are growing (Powell and Eddleston, 2008). Small businesses make over $99 \%$ of the UK economy ${ }^{2}$. Policymakers are keen on 'the mumpreneur' amongst other women business-owners, though some fear that mumpreneur businesses under-perform (Ekinsmyth, forthcoming). This is not a niche or economically insignificant interest.

'Mumpreneurship' is a spatial phenomenon. Mothers are creatively building businesses around the socio-spatial routines of daily child-care. Sometimes they capitalize on these time-space restricted routines and build or qualify their products around (or as a consequence of) them. A new entry (2011) in the Collins English Dictionary Online, defines the mumpreneur as 'a woman who combines running a business enterprise with looking after her children'. My own definition is more specific; it requires the mumpreneur to have configured her business around her caring role rather than simply juggle the two (Ekinsmyth, opt cite).

The following discussion is intended as a positive intervention in the forward momentum of the 'mumpreneur phenomenon'. The article draws on results from empirical research involving 30 in-depth interviews and 150 questionnaire responses with/from UK mother business-owners, and a poststructuralist discourse analysis of internet-based 'mumpreneur'-term debate (UK, USA and Australian - based sites ( $\mathrm{n}=8,151$ posts in total)). 
Discussion reveals that the views of 330 entrepreneurs (many of them 'mumpreneurs' as they are defined here), are sharply polarized on the 'mumpreneur' question. This polarisation can be understood as an impasse between those (optimists?) who see the phenomenon as a potential agent of social change (a new politics of motherhood or work?), and those who either don't see the need for change - or who believe the subject position 'mumpreneur' will cement current gender-role inequality. I will argue that the tenets of this debate resonate with contemporary academic debate about home-based, 'creative', and self-employed workers more generally, whose entrepreneurial labour is either framed as precarious on the one hand, or liberating/potentially transformative on the other (Gill and Pratt, 2008). This article progresses both these narrower and broader agendas.

After a short literature review and account of research methods, section 4.1, draws on the above definitions and presents a further delimitation of mumpreneur activities, while section 4.2 analyses the contours of the 'mumpreneur debate',. Section 5 situates these arguments within the broader realm of the currently shifting relationships between gender, work and family in contemporary affluent societies. I contend overall that the issues at stake here drive to the heart of feminist and wider debates around contemporary transformations in gender, work and place, and argue that 'the mumpreneur' may constitute a disruptive figure in gendered-labour politics.

\section{Literature - gender and work}

There is consensus that the 'New Economies' of Advanced Capitalist Nations demand a shift in labour practice (Presser, 2003; Edgell et al 2012; Gill and Pratt,2008). Evidence reveals that this shift is impacting differently on groups differentiated through axes of class, education, race and gender (McDowell,2008). Gender is implicated in iniquitous contemporary trends, encompassing not only extensification of working hours (Jarvis,2005), but also 'capitalism's penetration of workers' very souls' (Gill and Pratt, 2008,19) in the form of affective, emotional and immaterial labour (McRobbie,2011). In a recent special issue, Adkins and Jokinen (opt cite) identify the blurring of the boundaries between home and work as the 'fourth shift' in contemporary relations between these domains. Critically, this blurring entails, not just the movement of paid work into the home, but the redefinition of the use-value of labour so that immaterial, emotional and affective labour become part of the capitalist labour arsenal. Thus private (home), personal (family) and emotional domains become new resources for capital and, I contend, women's home-based labour is at the forefront of this attention. Blurring occurs because workers cease to realise where the boundaries are, when 
one is 'at work' and when one is 'at home', when one is 'working' or not. This brings centre stage, early materialist feminist arguments about redefining work and the value-producing nature of women's reproductive labour, as well as arguments about the falsity of 'separate spheres'; in a sense, the economy has caught up and realised how to capitalize on such labour in such places. However, as the articles in the special issue highlight, such shifts are not simply those of newly valuing, or the feminization of, women's work. Instead, they involve a reformulation of rules; a simultaneous re-assembling/re-entrenchment of the structural and ideological impediments to women's paid labour, and the discovery of new ways to exploit that labour (McDowell,2008; Adkins,2008). They conclude that in radical re-workings of aspects of life such as home, the politics of motherhood, and the politics of 'performative and all manner of affective and other overflows', the contemporary period is marked by 'the paradoxical erosion and intensification of gender' (Adkins and Jokinen,2008, 147). For the reasons given below, I contend here that 'the mumpreneur' embodies and perfectly exemplifies both this paradox, and the processes underlying it.

\subsection{Motherhood and work}

Discourses of intensive parenting (Hays 1996) are increasingly thought significant in studies of women's work, family and parenting (Blair-Loy, 2003; Ekinsmyth, forthcoming; Edgell et al 2012). Mantras of 'good motherhood' (Asher 2011) ranging in scope from breastfeeding and food culture to education, play and 'quality time', impact on young women who, according to McRobbie (2007), have been raised in a 'post-feminist' era of 'female capacity' and 'equality' (a framework which undermines any obvious need for feminism). These women expect to be able to negotiate the motherhood/work boundary under conditions of their own choosing, and finding otherwise, can be left with the lonely and painful dilemma of how to manage family and paid-work (McDowell,2005).

Despite Academic concern, 'good mothering' hegemonies are not contested or politicized enough in contemporary Western cultures. Commentators have identified contemporary, state-encouraged models of 'good mothering' that endorse active participation in the labour market (McDowell,2008; Adkins and Jokinen,2008). These are in contradiction to prevailing cultural and discursive constructions of the good mother (Hays,1996; Duberley and Carrigan,2012) that emphasize maternal presentism.

Indeed, large-scale surveys show that parents' workloads have intensified. Kan et al (2011) found that parents in the U.S.A. spent up to triple the amount of time on childcare in 2000 than they did in 1975, as well as more time on housework. Men's contribution had 
increased but women's too, had risen, despite their being more likely than twenty-five years ago, to be involved in the paid labour force. Hays (1996) typifies this activity as a hegemonic form of middle class motherhood, constructed as child-centred, expert-guided, emotionally absorbing (and exhausting), labour-intensive and financially expensive.

McDowell has argued that in the U.K., policy frameworks exacerbate rather than help the family/work dilemma $(2005,2008)$. Women's 'moral commitment to care', McDowell argues $(2005,373)$, can be viewed as a trade off between 'love and money'. She suggests that it would be a step forward for policy makers to acknowledge that the two are connected in a family's decision making regarding 'life's work' (Mitchell et al,2004). Other commentators have accounted for mothers' gender-role decisions at a family level in varying ways (for example family embeddedness - Moen and Sweet (2004); preference theory -Hakim (2000); role-identity -Rothbard and Dumas (2006)). A compelling contribution is from Leahy and Doughney (2006) who, critiquing Hakim's preference theory argue that the phenomenon of 'adaptive preferences' explains why some women 'opt out' of the formal labour market (or at least full-time work) upon having children. This isn't often, they argue, a result of pure preference or willingness but instead a preference position that has adapted to the structural realities of family life and societal pressures. Indeed, such decisions might be made from a position of little or no choice.

It is certainly vital to conceptualise the work 'decisions' of individuals at the family/household level and in terms of structure/agency (Jarvis,2005). The transition to motherhood is often the point where one's relationship to the world of employment and business ownership alters (Ekinsmyth forthcoming, Ekinsmyth et al,2004). For this reason motherhood roles and family-role decision-making have everything to do with mothers' market work (Duncan et al,2003; Glucksman,2006).

\subsection{Gender, mothering and entrepreneurship}

Given its scope for self-determination in working location and hours, coupled with the liberating potential of new ICTs, the evidence that women's entrepreneurship is increasing around the globe (Jalbert, 2000) is of little surprise. This is despite the fact that by all conventional business measures, women appear to underperform in business vis a viz their male counterparts (Powell and Eddleston,2008). To try to understand why, gender and entrepreneurship Scholars have recently turned their attention to discourses of entrepreneurship, which, they have argued, are thoroughly gendered (Ahl,2004, Jones,2012). Recent analyses of entrepreneurship discourses (policy, education and research documents 
(Jones 2012;Ahl,2004) conclude that these discourses are 'saturated with gendered meanings' (Jones,2012, 1). Entrepreneurial personality traits are discursively formulated as antithetical to femininity.

Women feel excluded from this subject position (Ahl,2004). But might this situation be changing for young women who are, according to McRobbie (2007), 'hyper-charged with economic capacity'? Whilst it is clearly important to differentiate women on the basis of class and race, it is also vital to differentiate women on the basis of life-stage. If womanhood is discursively 'other' to entrepreneurship, how much more so is motherhood? 'Economically capacitated' young women moving into motherhood find that suddenly, there is no suitable language to describe or evoke much of what they do. Discourses surrounding the self transmute from those of gender emancipation and female capacity to 'mumsy' discourses of the socially devalued (humdrum, cosy, but highly necessary) tasks that mothers perform. The ' 'fictive mother', marked by her corporeality, couldn't be more polarized from Jones's (2012) disembodied, masculine 'fictive entrepreneur'.

Despite acknowledging the demands of the motherhood role, research on women entrepreneurs with few exceptions, fails to acknowledge the differences between women with caring responsibilities and those without. A lack of particularist research has led to broadbrush understandings of the 'problems' that women entrepreneurs face. Some of these 'problems' (e.g. more limited success in raising business loans (Blake,2006)) undoubtedly apply more generally, but issues arising from social and geographical embeddedness will vary depending upon a woman's family status and geographical situation (Ekinsmyth,2011, forthcoming; Hanson,2009).

I have argued elsewhere that mothers as a specific sub-group of entrepreneurs are likely to face spatio-temporal restrictions that lead them to structure, organise and embed their businesses within family-friendly time-space routines (Ekinsmyth, forthcoming). Some discourses about women's entrepreneurship implicitly assume that all women's businesses face this situation whilst others fail to acknowledge this situation at all, preferring to frame women's entrepreneurial decisions in terms of economic or psychological factors. There is need for research that recognises diversity in women's entrepreneurship (and the places/spaces within which this occurs) and attempts to build new, positive (and feminized) models of entrepreneurial endeavour. In this spirit, the following account considers 'the mumpreneur'. Structured around the spatio-temporal routines of child-care, mumpreneurship demonstrates the relationship between gender, work and space/place with particular clarity. 


\section{Methodology}

Discussion in this article draws upon the results of a mixed-method study of U.K. mother business owners and an analysis of eight internet-based discussions located in U.K., U.S.A. and Australia. The wider research project (started in 2007) used methodological triangulation to understand the lives and businesses of UK-based, middle class mother entrepreneurs. Thirty in-depth interviews with early-stage business owners were selected through a multi-method case selection approach (snow-balling, word-of-mouth introductions and cold-calling). Respondents were chosen solely on the basis that they had started a business after transition into motherhood. Thus their businesses were diverse. In addition, questionnaire information was gathered from 50 (out of around 100) attendees at two conferences (the Birmingham 'U.K. Mumpreneur Conference' 2009, and the 'Mums in Biz 2010' conference in Brighton). A further 106 mumpreneur network members responded to a web-based survey in 2011. These data collection methods covered varying aspects of respondents' business/family lives as well as their attitudes to entrepreneurship and 'mumpreneurship'. Section 4.1 defines the dimensions of mumpreneurship on the basis of insights derived from this wider study.

The above empirical research threw up interesting divergences of opinion with regards to labels and identities for women's entrepreneurship. Especially interesting were conflicting views about the mumpreneur label. An Internet search revealed that this debate was also present in the blogosphere, so I chose to extend the range of voices in this discussion to include these debate participants $(n=151)$. Crucially, they represent voices that have arisen naturally within the community in question through business channels, rather than through research intervention. The evidence from the fora was thus triangulated with my research participant data.

The eight discussion fora were identified on 16.02.12 in response to Google searches on 'mumpreneur debate' and 'mompreneur debate'. I chose UK, USA and Australian debates. They vary in size from 3 to 51 posts (total number of individuals $=151$ ) and normally follow an opinion blog post from the Website owner about the 'mumpreneur' term. In addition, single blogs on the theme were also analysed $(n=3)$. As space in this article is limited, these provide the quoted data for the account in section 4.2. The details of each discussion fora (DF1-8) are given in the endnotes ${ }^{3}$. Each was solely about mumpreneurship. The quotation references to follow (e.g. DF7,1) refer to the discussion forum number followed by the page number upon which the quote is found when printed. Selected key quotes from the discussion fora are given below, representing the views of over 330 individuals (most of whom are mother or female entrepreneurs). 
Whilst remaining alert to the shortcomings and paradoxes at the heart of the approach, I adopted a poststructuralist discourse analysis to interpret the views of research subjects in relation to an '...institutionalized common sense that naturalises binary oppositions [male/female; proper entrepreneur/ someone 'playing at business'; businessman/mother] and the inequalities that they distribute' (MacLure,2003, 181). This article is concerned with social change and in particular the role that the new discourse of the mumpreneur may play in the shaping of these changes to social practices and processes.

At the macro-scale, Fairclough (2003) explains, discourses are networked in a particular way to constitute a social order, a dominant (or common-sense) way of conceptualising relationships (including power relationships) between different social actors and their practices. Discourses of the mumpreneur at the micro-scale are networked into discourses of gender, motherhood, gender contracts, paid work, separate spheres (to name some examples) at the macro-scale - this is what Fairclough calls 'the order of discourse' (206).

In this article, 'the mumpreneur' is conceptualised as a new discourse, one that is highly contested and one that has been inculcated by some, enacted by others and rejected/slated by many. The article speculates as to whether this new discourse can play a role disrupting the prevailing social (gender) order within business enterprise and work/family more generally, or whether it serves to reproduce traditional gender roles and identities. Indeed, maybe the two are not mutually exclusive.

\section{Findings}

\subsection{Delimiting 'Mumpreneurship'}

'I see it as a movement - it's gathering pace - lots of women looking for different ways to make their lives work. We are a group and there is a hierarchy.' (Winona, Founder of a UK-Internet-based, family-orientated gite-booking agency, Interviewee, 2010).

At the most basic level, mumpreneurship involves the configuring of a business around the spatio-temporal routines of child-care work. She is an important figure for economic geographers because she embodies the negotiation between time, space, gender, family and work. Whether or not the term 'mumpreneur' exists in a specific cultural context, it is my contention that this form of entrepreneurship exists. 
Mumpreneurship as an activity has quickly grown (globally) in the past decade, enabled by new ICTs. As a label for this activity, 'mumpreneur' appears to have emerged in the mid 2000's, simultaneously in the USA and the UK (a few individuals claim its coinage). The major players have been a handful of innovative women who saw the potential to build support/networking businesses around the emerging identity (for UK examples, see websites of 'MumpreneurUK', 'Mumsclub' or see Chitty (2011)). For these businesswomen/movement-makers, experts in social-media marketing, the promotion of the term/identity is tantamount to developing a product. Selling gendered, work/life balancerelated support, advice, networking events and internet-community, these businesses (linked internationally through cyberspace) have effectively supported and encouraged an activity/identity that policy makers are increasingly recognising (UK 'Mumsclub' owner, Jane Hopkins, was awarded an MBE in 2011 for services to women's entrepreneurship). Award ceremonies, circuits of conferences and inspirational mumpreneur speakers, promoted by these key marketing professionals have become commonplace (in the UK since 2009 - first MumpreneurUK national conference). In the UK, they have filled a gap in women's entrepreneurship support provision left by Government austerity measures. The 'mumpreneur movement' is thus an organic movement whose consequence is an identity that is still under construction. Currently in many countries, whether labelled in this way or not, the movement is rapidly advancing through these mechanisms.

My interviews and questionnaires revealed however, that some did not like to be labelled a 'mumpreneur', whilst others drew varied benefits from this identity position. Media habit, of ascribing the label to any woman business-owner who happens to be a mother, undermines the credibility of this subject-identity. The interview and survey results revealed that there are various potential mumpreneur business practices, and many mothers' businesses fall outside of these. I here propose a three-fold differentiation under the headings business practice, identity and product qualification. It is important to emphasize that individual businesswomen may adopt any combination of these practices - although to qualify as a mumpreneur, they need to have configured their business around their children.

I contend that all mumpreneur businesses adopt the 'business practice' aspect (though not necessarily all the possible components of it). If business owners claim that they have started and (crucially) configured their business in such a way as to better manage the workfamily boundary, then they are 'mumpreneurs'. This definition needn't exclude fathers who construct their businesses for the same ends. It is hard to estimate how large this group might be as statistics are limited. Wiseman et al (2006)(reporting on findings from the Small 
Business Survey 2004-5) reported that $21 \%$ of women and $2 \%$ of men cite family commitments as the reason for starting a business but these are likely to be under-estimates. Many of the aspects of this practice are spatial (Ekinsmyth 2011, 2012, forthcoming). These aspects are; working around family commitments within neighbourhood-based, limited timespace routines of motherhood; low-cost, low-risk start-ups; use of local, social contacts for business networking; working in family spaces (often the home); reliance on ICTs and social media; rationalised acceptance of traditional gendered divisions of labour. This is the most obvious, commonplace and the most 'geographical' form of mumpreneurship and for many mumpreneurs, it is the only one of the three aspects adopted.

Some mumpreneurs additionally adopt an entrepreneurial identity that is distinctive amongst a further sub-group of the wider mumpreneur group (in Fairclough's (2003) terms, they have inculcated rather than simply enact the mumpreneur discourse). For these women, it is a source of pride that they reject accepted 'text-book' forms of entrepreneurship and business practice. They self-consciously endeavour to practice a form of entrepreneurship of their own creation, and prioritise motherhood as an identity amidst which and through which their mumpreneurial identity is carved. These women will often, though not always, embrace the term 'mumpreneur' and apply it to themselves, but won't necessarily use it in the branding of their businesses, products or services.

Finally, there is the 'product' aspect of mumpreneurship, attributable to a further and the smallest sub-group. These women have built a business around their identity and activities as a mother, and use the term as a label and marketing lever. In other words, these businesses are promoting the mother-identity of the embodied business owner as an integral component of their unique selling point, product or service. Mumpreneurship and motherhood here are a form of product (or service) qualification (Callon et al,2002). Such businesses creatively and often profitably use the term 'mumpreneur' to their advantage.

Thus mumpreneur businesses are varied and differentiated. It is clear from the discussion that follows that fora contributors held varying understandings of the phenomenon and were situated variously in relation to the three sets of aspects outlined above.

\subsection{The 'mumpreneur' debate}

Having delimited 'mumpreneurship' as a (gendered) type of business practice, the following section will consider the Internet debates about this business identity. I posit that the stakes are high in such debates (irrespective of the future longevity of the term) because the underlying disagreement centres on mothers' continuing and future relationship to the labour market vis a 
vis their family roles. The analyses to follow thus provide insight into the relationship debatecontributors have with gendered identity, motherhood identity, work, labour markets and feminism. As this section will argue, these debates reveal a deeply paradoxical situation that drives to the heart of the issues regarding women and work in the democratic societies of the contemporary West.

All discussion streams were originated by a blog from the website/business owner (they were mostly mothers' business network websites), which forwarded a strong argument, for or against, the mumpreneur term. Thematic coding of the discussion streams and survey respondents' views identified 50 resulting different forms of objection to the term 'mumpreneur' and 44 different forms of expression of approval. Debate content did not vary by country of origin, but rather, the issues raised appear to be universal. One discussion stream contained mostly negative views in response to a very strong negative blog, but the others were balanced. The varying views were further aggregated in an iterative process to a summary six general debate themes, each comprising stark differences of opinion. These themes substantially overlap, and in the following section, they are further-grouped into three sub-sections; 1. Sector/business type; 2. Business and motherhood identity; 3. Gender roles, language and politics. For simplicity in this short article, only fora discussion views are quoted, but the following discussion represents the findings of all the research data.

\subsubsection{Sector/ business type}

At their simplest level, these debates manifested around business image. Many contributors were critical that the mumpreneur label implied a certain type of business or product. Accordingly, they worried that the label would have negative consequences both for business 'pigeon-holing', and, more generally, for the image of all women entrepreneurs. The size of the business, in terms of scope and ambition, was one implication they felt. The following sentiment is fairly representative of such views:

'I do have a bit of a problem with the word 'mumpreneur'. To me, it conjures up all kinds of cosy images of women running friendly little businesses selling something appropriate, in between baking scones and doing the housework.' [df2, 1]

Aside from the fairly derogatory image of motherhood presented here (dealt with later in the article), the implication is that a mumpreneur business will be small and un-ambitious. 
These commentators thus felt that a woman would 'down-play' her business by using the label.

There was feeling too that the term inappropriately conjured up a specific sector and form - for example: 'I think there is certainly an association between the term mumpreneur and online businesses that sell baby products and similar. ' [df2, 2] These commentators were worried that, in terms of business image, associations, whether right or wrong, between 'mumpreneur' and business sector/type, would consign mothers' businesses to be taken less seriously, whether or not they adopt the label for themselves. Furthermore, the tendency for intra-mumpreneur networking, was thought by some, to have equally negative (ghettoizing?) consequences:

'As a 40+ woman who recently set up a business, I've seen a lot of 'mumpreneurs' on Twitter - intelligent and competent women who seem to be hiving themselves off into an entrepreneurial ghetto - a safe and fluffy place that to be honest, comes across as a bit smug to a non-mum. It seems the starting place of the mumpreneur movement was to provide much-needed support and information, but the danger is it'll hold women back in some kind of stasis of underachievement.' [df2, 3]

Those in favour of the label conversely, tended to emphasize the networking, support and marketing advantages of the mumpreneur label and 'movement'.

\footnotetext{
'Whilst many people are not keen on the term 'mumpreneur' we are a group who receive no support. There are networks out there for entrepreneurs, women in business, men in business and the likes but nothing that accommodates mums. After working in sales, selfemployed, I found it increasingly hard to get people to take me seriously once they heard a little one in the background and, unbelievably, this can still cause a problem. We are trying to create a network of women who all live with the same pressures.' [df2, 5)
}

Many contributors reflected that the 'mumpreneur' identity and networking possibilities have contributed favourably to their image of themselves as women who can start and run a successful business:

'Any business descriptor that opens the doors of opportunity or builds a sense of collective belonging is a righteous step in the right direction' $[\mathrm{df1}, 14]$ 
Beyond networking and belonging, there is also a powerful business profit-motive and benefit for some. The use of the term 'mumpreneur' as a marketing and public relations tag is a powerful tool for businesses that target - in part or fully, the parent or parenting market:

'From a PR perspective, it's a useful tag at the moment certainly'[df2, 9.]

Additionally, in sectors that aren't related to parenting products and services, 'mumpreneur' can be a powerful USP (Unique Selling Point). Some practitioners claim that mumpreneurnetworking spaces, traditional (for example mumpreneur conferences and meetings) and virtual (blogs, social media, Internet), feature as important spaces (the 'mom-space' - as the quote below refers to it) for business generation:

\footnotetext{
'These mumpreneurs should think of it as an additional conduit for marketing opportunities - a mompreneur can be marketed into the mom space (blogs, media) or be marketed as a more traditional entrepreneur.' [df7,6]
}

The discussion fora revealed that for every argument forwarded that the mumpreneur label could be damaging for business, a counter claim could be made that it can be positive. On pure business grounds, it is clear that the nature of the business and the sector in which it is placed, are important determinants of whether or not the label could be a useful addition to the business arsenal.

\subsubsection{Identity, motherhood and business}

Given the impasse that motherhood and paid work are not thought to sit easily with each other, the emergence of a business identity built around motherhood opens up questions about the value (potential for a disruptive politics?), intent or implications of this identity. There is much disagreement.

Some saw the term as insulting, questioning why women entrepreneurs should have gendered role-identities attributed to their work-identities simply because they happen to be mothers. They argue that fathers are not similarly treated and (some) decry the mumpreneur label as anti-feminist. As one male contributor argued:

'...There aren't dadpreneurs. If anything mumpreneur puts an asterisk by a female entrepreneur's accomplishments as if to say one is 'only' a mumpreneur. As if it's something they play at between being a mom, or as if they're not really entrepreneurs. I know plenty of people, men and women, who only play at doing what they claim to be 
doing, and to stick a title like mom in front of a word says they don't take it seriously.' $[\mathrm{df} 1,4]$

The assumption here that the word 'mom/mum' suggests that the business is something that is 'played at' is worthy of attention. Some who like the label, adopt it as a way of distinguishing themselves from a conventional (masculinist) version of the 'entrepreneur'. They believe they are doing something different, forging new ground and establishing a new, feminised version of entrepreneurship practice. The assumption that when women (or some other 'marginal' group) do this, they are establishing an inferior version, or not taking the conventional (male) practice seriously is missing this point. The object is not to join men in a man's game, but to establish a woman's game, and practice, publicize and in time, legitimize it. The following contributor expressed this view:

\footnotetext{
'When are we going to stop trying to make all women-owned firms fit into a 'proper' male-defined model? We'll all benefit from legitimizing a diversity of approaches and monikers.' $[\mathrm{df} 7,9]$
}

I return to this subject in section 4.2.3.

It is interesting that the crux of this disagreement seems to be whether it is damaging or liberating for women to 'own up to' their gender-related family situations (the work/family juggling). It is also interesting that we need to think in terms of 'coming clean' about motherhood. That this is still an issue is indicative of so much that remains to be gained in the realm of gender equality and work. The 'mumpreneur debate' highlights this well.

Indeed, underpinning a good number of negative comments about the mumpreneur term were negative associations with the mother-identity, and more particularly, negative attitudes towards motherliness. Derogatory comments involving words like 'cutesy', 'cosy' and 'homespun' were common, words that are associated with 'mother' and not 'entrepreneur'. These commentators didn't seem to be able to get beyond the word 'mum' in 'mumpreneur', seeming to have traditional views of mothering and caring. The emotional or 'soft' labour of motherhood seemed to suggest to them that the mumpreneurs' business activities would be soft, petty and lacking in seriousness. Again, this highlights a far more general set of circumstances in societies where mothers and motherhood tend to be considered in this (inferior) way (Johnson and Swanson,2006). 
There were commentators who were against the idea of attributing a 'special label' to mother-entrepreneurs. This could be viewed as a form of gender-blindness. One contributor asked:

'Why do you need a special label because you are a Mum?... Let's celebrate the achievements of all entrepreneurs and not invite 'special labels' or 'dispensations' on the grounds of gender and fertility! Equality via achievement first and foremost.' (df1,6).

'Special label' detractors appear to assume a 'level playing field' between mothers and men/non-mothers. As this male contributor argued:

\footnotetext{
'Successful business women and entrepreneurs are just that: successful business women and entrepreneurs... I would much rather appreciate a business woman's achievements for her achievements, not because she is a woman and why on earth do some feel extra credit is required for having been able to multi-task too?' $(\mathrm{df} 1,6)$
}

The association with 'multi-tasking' made here is a common one. It seems that the combining of the two identities into one word - 'mum' and 'entrepreneur' suggests to some, a special (or extra) form of multi-tasking that they feel is undeserved (in terms of credit, exception or remark):
'Am I a mum in business? Yes. Is that all that I am? No. I'm a woman in business...wait... a person in business. I'm also a dog owner, a fan of socialising and travel. All of these things also have to be juggled around my business ventures but there is no term coined for them... I don't feel I need a pat on the back for organising a business around my daughter.' (df1,11)

For some, as the above quote demonstrates, the label is also seen as patronising because for them, it has connotations of women being congratulated for being simultaneously mothers and entrepreneurs. It appears that the fact that a category of entrepreneur is singled out, for these commentators, is tantamount to congratulation or celebration. This interpretation may arise from the practice within mumpreneur networking circles of awarding prizes for mumpreneur achievements ${ }^{4}$.

Many contributors had drawn practical benefits. Irrespective of personal experience of participating in mumpreneur networking events/groups, for these women, the existence of the identity position was positive and inspiring. Furthermore, whilst fora contributors focused on 
the value of the term as an inspiration to mothers to think about entrepreneurship, it was clear from the interviews undertaken with 'mumpreneurs' that for many women, mumpreneurship was offered a way of doing business differently. These interviewees drew pride from the fact that they felt part of a movement that was recasting the (masculinist) rules of entrepreneurship (Ekinsmyth,2011). One forum contributor expressed views of a related nature:

\footnotetext{
'Some have suggested that the term takes us back to a time when women were relegated to the house, but I feel it does the exact opposite. To my mind those women who wish to hide the fact that we are mothers in the workplace are bowing to pressures they perceive from other quarters. What could be more inspiring and more admirable than to coin a phrase that tells the world women can be all they want to be cerebrally without having to compromise on all they wish to be maternally.' $\{$ df 1,8$]$
}

The political value of the mumpreneurship trend is further considered in the next section.

\subsubsection{Separate spheres, language and politics}

'Wouldn't it be nice if juggling family and business just became 'what people do' rather than a mumsy ghetto?' [df2,3]

There was considerable debate about whether the term 'mumpreneur' challenges, reinforces, normalizes or simply acknowledges separate spheres, gender norms and indeed, negative stereotypes of women entrepreneurs. Some felt it progressive in itself that the term had surfaced debate around these issues in the public realm.

For some, it was positive that in the business world, the term has worked to highlight the fact that mothers' lives are generally different to fathers', and different too, to those of women without dependents:

'... of course, like it or not, being a businesswoman (especially one who runs a business from home) when you have children presents its own set of challenges, which are not encountered by businessmen or women who are not also full-time parents. It is more than 'having a family life' - my husband does that, but he does not have to fit his full time job around school runs, sickness, nativity plays, homework etc etc.' [df2,4]

Whilst some saw the term as unnecessary and anti-feminist, others saw it as an opportunity to mainstream the working mother and break down separate spheres: 
'I think the more mainstream these concepts become, actually the more motherhood can be valued in and of itself (I can't bear the 'just a mother' sentiment!) and the worlds of parenting and business can be made less polar.' [df2,5]

Other detractors felt that the term was smug and exclusionary. Their view was that it was (yet another) example of the 'Mum- or parent brigade' claiming superiority and exception. As one writer reflected, '...part of me thinks there are already enough messages in society that parents are inherently superior to people who don't have kids.' [df1,19]. Quite clearly, some of the disagreement stemmed from the differences in personal circumstances between contributors. Far from being a platform from which to gloat or feel smug, for some, it represented a positive label that might overcome some of the negative feelings that can accompany mothers in the quest to find a balance between paid work and family:

'I see a lot of guilt in the moms I know - guilt because they are working or guilt because they aren't. It's nice to see a positive label that empowers women and if they want to use it, who am I to argue?' [df1,19]

The longer discussion streams (DF1,2,7 and 8) debated how to define the term, its power, and possible effects. There was unrest that despite liberal use of the term, people understood the practice it represents differently. It seems likely that the term is misunderstood and contested precisely because it denotes a female identity that is both new, and, newly acknowledgeable - that is, a mother who is successful in business and, a business-woman who does not feel the need to hide her family-role in order to be taken seriously.

Those who use the term to describe themselves appear to adhere to varying definitions. Some defined a mumpreneur as a mother who has designed a business around her mothering responsibilities (to which I concur); whilst for others, it was about an entrepreneurial identity that refuses to partition the dual roles of entrepreneur and mother:

‘...I unapologetically 'own' calling myself a 'mompreneur' because it clearly defines who I am - to myself and to the larger world - by combining the two most important aspects of my life.' [df7,7]

Still others understood mumpreneurs to be those who fill a parenting-related niche in the market. In some ways therefore, debaters are arguing about different things.

For mumpreneurship to possess greater disruptive potential in entrepreneurship discourse, the identity needs to be better defined and more consistently understood. Without 
this clarity, judgements that the term assumes (and thus further naturalises) women's unequal gender roles, and represents a potentially damaging discourse are difficult to dismiss. Indeed the power of language to effect change or to reinforce the status quo, was the crux of some of the arguments in these discussion streams. And whilst many commented at the level of individual experiences, freedom and opportunity, some were more concerned about gender relations at a societal and political level:

\footnotetext{
'The term 'mumpreneur' fascinates me. It is arguably the beginning of a new phase in feminism and one that I welcome and whilst I don't think the term is an elegant one, I love what it represents. I like it because it has something of the rebel about it. It is an audacious phrase that suggests we are not just trying to fit in to a still very male oriented environment but women who are comfortable enough to say that they can work and be mothers with an emphasis on the desire to be hands on when it comes to our families.' $[\mathrm{df} 1,8]$
}

Similarly for many, the permission /opportunity to do entrepreneurship differently was main attraction. The key question this debate raises is, how instrumental a phenomenon like "the mumpreneur' can be in effecting (or stalling), change in ideology about who is 'fit' to work and under what circumstances?

\section{Discussion: The wider implications of the 'mumpreneur debate'}

These debates are 21st century feminist issues, gaining exposure now because the blurring of motherhood and business is newly enabled through rapidly advancing information and communication technologies. Such blurring enables new geographies of (gendered) work and Mumpreneurs are capitalising on this, but hegemonic ideologies of gender identities are lagging behind.

The research subjects, many living with the dilemmas they describe, held varying understandings of how to achieve greater equality for women (business-owners). Some argued that defining women's work through a feminine-gendered label or identity ('mother') reproduces gendered stereotypes and risks ghettoizing women's businesses. Others saw no need to gender entrepreneurship at all. There were also those who heralded the term and it's implications as a form of resistance to narratives, and thus prejudices, in societies that construct entrepreneurship as masculine. Many contributors also highlighted the strength to be gained from identifying a group to which you belong, in terms of identity, legitimacy, 
networking, visibility and publicity/marketing leverage. Thus there were liberal and radical feminist, anti-feminist, activist and autonomist viewpoints in conflict with one another. To sum, mumpreneurship was varyingly represented as precarious, insignificant, or emancipating/transformative.

The debates reveal that the identity of 'the mumpreneur' is mired in the complexities of the structure/agency dualism. It is indeed a danger that mumpreneur activities operate within some of the confines of gender-prescribed norms; they enable a mother to carve her work around her family within the spatial sphere of everyday family life (usually the home/neighbourhood). This can limit a business in its early stages and send out a message that mothers' businesses aren't serious. On the other hand, such socio-spatial confines encourage a level of creativity that can bring about new, innovative business practices and forms (Ekinsmyth 2011). My research (opt cite) reveals that many women want to be the main player in their family lives, and whilst it is beyond the realm of this article to extend discussion into the bases of gendered subjectivities, it is clear from the accounts above that many mumpreneurs are pleased to be able to run businesses whilst simultaneously deriving satisfaction from 'good' mothering. This is usefully conceptualized in terms of 'adaptive preferences' (Leahy and Doughney,2006) or, the exercise of agency within structural constraints.

Women's work is partly constructed in the realm of discourse. It is thus useful to deconstruct the word 'mumpreneur', which is regarded as trivial and trivialising by many. It is instructive to ask why. The discussion fora debates reveal that the work of motherhood is discursively constructed as trivial and antithetical to 'real' work. In the economic and business realm, feminist texts besides, words and concepts associated with the labour of motherhood are non-existent (unless the mother is being targeted as the consumer). Furthermore, a paradoxical situation exists that mothers' work is taken all too seriously by policy discourses and parenting 'experts' (that blame the 'breakdown of the family' on working mothers); but little value is placed on the actual tasks that mothers perform. The 'work of love' (Rich,1976); childcare tasks, domestic tasks and household management, the 'immaterial labour' of parenthood (much of which often falls to the mother), are trivialised to the extent that there is no 'serious' language to evoke it. This is the invisible and silenced labour of motherhood. It separates mothers from non-mothers. Without appropriate language, it is an unspeakable and unspoken discourse (Stadlen,2004). 'Mumpreneurship', thus, is alien.

This paradoxical and concurrent fetishization and trivialisation of motherhood presents an enduring problem to the mother-entrepreneur. As the 'mother' is discursively and culturally 
constructed as a great deal more trifling than the 'entrepreneur', the 'mumpreneur' can thus be read as a less serious, more limited, rather female version of the real (masculine) thing. This term thus risks reproducing, rather than challenging, negative gendered stereotypes. Herein lies the practical issue at stake with the term and identity 'mumpreneur'. Motherhood, until now, is the identity that dare not speak its name in the business world.

The discussion fora demonstrate that an even more foundational, but related problem for women entrepreneurs is one of demarcation. Whilst feminists have critiqued the totalising claims of taken-for-granted masculinist discourses, they have struggled to avoid totalising discourses themselves (Butler,1990). Gender as a concept poses this problem from the outset, as do categories 'man', 'woman', 'masculine', 'feminine', 'mother' and 'father'. Whilst critiquing the construction of these categories, the language and political imperatives require us to use them, through using them, we run the risk of reproducing their structural power and taken-for-grantedness. Thus categories such as 'woman entrepreneur', 'ethnic entrepreneur' and especially perhaps 'mumpreneur', mark these groups as different (and potentially inferior) to the disembodied, masculine entrepreneur norm. Such categories can be rightly criticized for their underlying essentialism, though feminists have long been of the view that strategic essentialism is an important feminist strategy. In terms of gender politics then, the issue is whether we do women a disservice by naming, identifying and discriminating between women entrepreneurs/business owners. This problem does not only apply to Mumpreneurs, but to workers generally when they are given the prefix 'women'.

A related issue that faces women entrepreneurs is that in policy discourses and many academic accounts, women's entrepreneurship is conceived as a problem that needs to be fixed (Marlow and Patton, 2005). It is commonly conceived as an issue, for example, that UK women's entrepreneurial start-ups are currently $49 \%$ of the rate of men's (Levie and Hart,2011). Whilst funding and special initiatives have been withdrawn during the current recession in the UK (www.womensenterprisetaskforce.co.uk), it remains a policy objective to encourage more women into business ownership. Negativity in popular and academic discourse does not help the issues at stake. Women who are less able to play the 'male game', those embedded in routines of family care-work, need positive role and business models that reveal ways of doing and structuring a business around the spatio-temporal routines of family care. In the figure of the 'mumpreneur', promoted by buoyant mumpreneur networks and their associated events, popular culture has delivered a subject identity that takes the masculine out of 'entrepreneur' (but in so-doing succumbs to negative hegemonic stereotypes about women's businesses). 


\section{Conclusions}

Drawing upon practitioners' accounts, this discussion has considered the gender politics beneath the increasingly prominent subject of the mother business owner or 'mumpreneur'. The article has focused on the discoursal realm, in contrast to previous articles where I have considered the material (Ekinsmyth 2011, forthcoming). Discussion has revealed that the differently valued subjects of 'mother', 'worker', 'entrepreneur' and 'mumpreneur' are discursively co-constituted through the power of discursive definition. For the poorly rated mother-entrepreneur (and 'mumpreneur'), I contend that academic, policy and everyday business practice discourse need to be challenged. This article is, in part, a contribution to this challenge.

Analyses here of the popular arguments circulating about mumpreneurship have revealed the related need for a carefully defined and understood conceptualization of mumpreneur activities. This article has forwarded a nuanced and detailed definition.

Throughout the article I have asked whether 'the mumpreneur' can act as a force for positive change in gender politics? Both the discussion fora, and the mumpreneur interviews, reveal that to answer this question, we need to place significance on the meaning that individual mumpreneurs attach to their blurred mother/entrepreneur identities, and the everyday lived experience of combining these subject positions. For many, the growing phenomenon of the 'mumpreneur' represents a positive step. The business world is renownedly masculinist (Jones 2012), in the mumpreneur, a self-proclaimed, overtly female business identity has emerged, that represents a different way of doing business - one that creatively merges the spheres of re-numerated work and family. It currently offers mothers new possibility, and may just initiate positive structural change in discursive and material realms across the coming years.

Mumpreneurship is a spatial phenomenon. The spatial separation of 'work' from 'home/family', long considered a foundational element of gendered divisions of labour in industrialised countries, is rapidly eroding in the 'New Economy' (Edgell et al 2012). Globalreach, home-based technologies are opening up new potential for work/life balance and possibilities are rapidly changing. While this might re-entrench and further naturalise couples' gendered divisions of labour, it represents a chance for mothers, albeit arguably working from adaptive preferences, to start businesses that can grow in-step with their families. Many have enjoyed considerable business success (Ekinsmyth, forthcoming). Mumpreneurs are at the forefront in seizing the opportunities that these new ICTs bring. 
There are undoubtedly further good reasons for concern, however. The darker side of mumpreneur working practices, the potential for self-exploitation, workaholism, hidden labour (emotional and affective) and the newly enabled practices (through ICT and social networking) that bring capitalism firmly (and potentially damagingly) into the realm of the family, its life and loves, have not been touched upon in this article. They are a pressing issue for future research. Necessary too is further research on intersectional factors, notably the class-based nature of mothers' entrepreneurship (mumpreneurship appears to be a middleclass phenomenon (Ekinsmyth 2011)). In terms of future policy implications, policy makers in women's entrepreneurship and more generally need to deliver support that recognizes more fully the family contexts within which mothers' businesses commonly operate. They also need to re-frame discourses and thinking about women entrepreneurs (and women workers more generally) so that they are not discussed as a problem or lesser version of the male norm. This discussion has highlighted the value, at many levels, of feminised worker-identity positions that enable group-identity formation, networking, feelings of belonging, marketing and role model inspiration. Experience shows that many mothers value events and interventions that are aimed directly at them. Mumpreneurs have been keen to exploit this 'mumspace', policy interventions are lagging behind.

This article has argued that the issues beneath the arguments about the mumpreneur drive to the core of contemporary uncertainty and change in relationships between gender, work, place and family. It has explored these uncertainties through the mumpreneur-debate lens. This lens illuminates the still murky waters for mother-workers, but also hints at the potential (with its pitfalls) for future identity-blurring, family-role to work enrichment and work/life harmony.

\section{Acknowledgements}

I should like to offer my thanks to Jenny Sjoholm, Karenjit Clare and Simon Leonard for their comments on an earlier draft of this paper, and to the helpful advice received from three anonymous Referees and the Editor of this Journal. All very much appreciated.

\section{Notes}

1. E.g. www.mumpreneuruk.com

2. House of Commons Briefing Document, 09/2012

www.fsb.org.uk/policy/images/fsbwestminster01\%2012\%20(3).pdf

3. Discussion Fora 1-8: 
1. socialable.co.uk - website of UK. based Mumpreneur-of-the-Year award winner Lilach Bulloch (Social-Media Marketing Coach and Speaker). Lilach posted a blog (21.11.11) - extolling the virtues of the label - 27 comments resulted (DF1). (www.socialable.co.uk/mumpreneur-is-offically-recognised and-entered-in-the-dictionary/

2. whosethemummy.co.uk - website of UK-based Journalist, Social-Media Marketing Adviser and Blogger Sally Whittle. Posted blog (05/10/09) arguing that the label is potentially damaging to businesswomen - 30 responding comments (DF2). (www.whosethemummy.co.uk/Why-don't-fathers-get-calledDadpreneurs-html)

3. Learningmadefun.co.uk. Blog from Founder Karen Sherr -3 responses (DF3)(www.learningmadefun/2011/06/what's-your-view-on-the-term-mumpreneur.html)

4. Littlesheep-learning.co.uk. Blog from Founder Elaine - 4 responses. (DF4)( www.littlesheeplearning.co.uk/blog/2011/mumpreneur/)

5. Mumpreneursonline.com. Australia-based Fiona Lewis, Business Founder and Author. Her post attempts to define the term - 11 responses. (DF5) ( www.mumpreneursonline.com/mumpreneurs/the-definition-of-a-mumpreneur)

6. Thebusinessbakery.com - the website of Australia-based Julie Bickerstaff - 4 responses (DF6) (http://thebusinessbakery.com.au/_blog/The_Daily_Juice/post/That_Mumpreneur_word/)

7. Forbes.com - US-based Internet business news - online discussion following article (04/10/11) by Forbes staff Meghan Casserly - 'Mompreneur:' Own it, ignore it or prove it wrong' - an impartial post with 14 resulting comments (DF7) (www.forbes.com/sites/meghancasserly/2011/10/04/mompreneurown-it-ignore-it-or-prove-it-wrong/)

8. Muminthemadhouse.com - website of UK-based business founder Jen Walshaw, Freelance Project Manager, Writer and Blogger. Her blog (6/6/11) is about how much she hates the mumpreneur label - 51 responses, mostly agreeing with her. (DF8) (http://www.muminthemadhouse.com/2011/06/06/mumpreneur-why-would-you-call-yourself-that/)

4. See for example www.mumpreneuruk.com/celebrate/mumpreneur-awards

\section{Notes on contributor}


Carol Ekinsmyth is a Principal Lecturer in the Geography Department at the University of Portsmouth. Her interests lie in the relationship between economic practice and social relations (specifically at present, gender relations), at the level of the individual practitioner and their everyday lived experiences. Her work in economic geography has focused on various practices of self-employment, and her most recent empirical research has investigated the phenomena of small-scale entrepreneurship carried out (and started up) within the context of motherhood, family life and home/neighbourhood space ('mumpreneurship').

\section{References}

Adkins, Lisa, and Eva Jokinen. 2008. "Introduction: Gender, Living and Labour in the Fourth Shift.” NORA - Nordic Journal of Feminist and Gender Research 16 (3): 138-149.

Adkins, Lisa. 2008. "From Retroactivation to Futurity: The end of the sexual contract? NORA - Nordic Journal of Feminist and Gender Research 16 (3): 182-201.

Ahl, Helen. 2004. The Scientific Reproduction of Gender Inequality: A Discourse Analysis of Research Texts on Women's Entrepreneurship. Koege: Copenhagen Business School Press.

Asher, Rebecca. 2001. Shattered: Modern Motherhood and the Illusion of Equality. London: Vintage Books.

Blair-Loy, Mary. 2003. Competing Devotions: Career and Family Among Women Executives. Cambridge MA: Harvard University Press.

Blake, Megan. 2006. "Gendered Lending: Gender, Context and the Rules of Business Lending." Venture Capital 8 (2): 183-201.

Butler, Judith. 1990. Gender Trouble: Feminism and the Subversion of Identity. London: Routledge.

Callon, Michael, Cecille Meadel, and Vololona Rabeharisoa. 2002. "The Economy of Qualities." Economy and Society 31 (2): 194-217.

Chitty, Antonia. 2011. The Mumpreneur Guide: Start Your Own Successful Business. London: Bookshaker.

Duberley, Joanne, and Marylyn Carrigan. 2012. “The Career Identities of 'Mumpreneurs': Women's Experiences of Combining Enterprise and Motherhood.” International Small Business Journal 30 (2): 1-23. DOI: 10.1177/0266242611435182.

Duncan, S., R. Edwards, T. Reynolds, and P. Alldred. 2003. "Motherhood, Paid Work and Partnering." Work, Employment and Society 17 (2): 309-330. 
Edgell, Penny, Samantha Ammons, and Eric Dahlin. 2012. "Making Ends Meet: Insufficiency and Work-Family Coordination in the New Economy. "Journal of Family Affairs 33 (8): 999-1026.

Ekinsmyth, Carol. Forthcoming 2013. "Managing the Business of Everyday Life: The Roles of Space and Place in 'Mumpreneurship'." International Journal of Entrepreneurial Behaviour and Research.

Ekinsmyth, Carol. 2012. "Family Friendly Entrepreneurship: New Business Formation in Family Spaces." Urbani Izziv 23 (s1): S115-S125. DOI: 10.5379/urbani-izziv-en-201223-supplement-1-011.

Ekinsmyth, Carol. 2011. "Challenging the Boundaries of Entrepreneurship: The Spatialities and Practices of UK 'Mumpreneurs'." Geoforum 42 (1): 104-114.

Ekinsmyth, Carol, Rebecca Elmhirst, Sarah Holloway, and Helen Jarvis. 2004. "Love Changes All: Making Some Noise by 'Coming Out' as Mothers." In Geography and Gender Reconsidered, edited by Joanne Sharp, Kath Browne, and Deborah Thien, 95107. Available at http://wgsg.org.uk/newsite1/pdfs/introduction.pdf.

Fairclough, Norman. 2003. Analysing Discourse: Textual Analysis for Social Research. Abingdon: Routledge.

Global Entrepreneurship Monitor (GEM) Women's Report. 2010. www.gemconsortium.org/docs/download/768.

Gill, Rosalind, and Andy Pratt. 2008. "In the Social Factory? Immaterial Labour, Precariousness and Cultural Work." Theory, Culture and Society 25 (7-8): 1-30. Glucksman, Miriam. 2006. "Shifting Boundaries and Interconnections: Extending the "Total Social Organisation of Labour".” In A New Sociology of Work?, edited by L. Pettinger., J. Parry, RF. Taylor, and M. Glucksman. Oxford and Malden MA: Blackwell.

Hakim, Catherine. 2000. Work-Lifestyle Choices in the 21st Century: Preference Theory. Oxford: Oxford University Press.

Hanson, Susan. 2009. “Changing Places Through Women's Entrepreneurship.” Economic Geography 85 (3), 245-267.

Hays, Sharon. 1996. The Cultural Contradictions of Motherhood", New Haven and London: Yale University Press.

Jalbert, Susanne. 2000. Women Entrepreneurs in the Global Economy. Washington DC, Centre for International Private Enterprise. 
Jarvis, Helen. 2005. "Moving to London Time: Household Coordination and the Infrastructure of Everyday Life.” Time and Society 14 (1): 133-154.

Johnston, Deirdre, and Debra Swanson. 2006. "Constructing the "Good Mother": The Experience of Mothering Ideologies by Work Status." Sex roles 54 (7-8): 509-519. Jones, Sally. 2012. "Gendered Discourses of Entrepreneurship in UK Higher Education: The Fictive Entrepreneur and the Fictive Student.” International Small Business Journal:122. DOI:10.1177/0266242612453933.

Kan, Man Yee, Jonathan Gershuny, and Oriel Sullivan. 2011. “Gender Convergence in Domestic Work: Discerning the Effects of Interactional and Institutional Barriers from Large-Scale Data.” Sociology 45 (2): 234-251.

Leahy, Mary, and James Doughney. 2006. "Women, Work and Preference Formation: A Critique of Catherine Hakim's Preference Theory." Journal of Business Systems, Governance and Ethics 1 (1): 37-48.

Levie, J., and M. Hart. 2011. Global Entrepreneurship Monitor: United Kingdom 2011 Monitoring Report, GEM UK.

Marlow, Susan, and Dean Patton. 2005. "All Credit to Men, Entrepreneurship, Finance and Gender". Entrepreneurship, Theory and Practice 29 (6): 699-716.

McDowell, Linda. 2008. "The New Economy, Class Condescension and Caring Labour: Changing Formations of Class and Gender". NORA - Nordic Journal of Feminist and Gender Research, 16 (3): 150-165.

Mcdowell, Linda. 2005. "Love, Money, and Gender Divisions of Labour." Journal of Economic Geography 5 (3): 365-379.

McRobbie, Angela. 2011. "Reflections On Feminism, Immaterial Labour And The PostFordist Regime.” New Formations 70 (17): 60-76.

McRobbie, Angela. 2007. “Top Girls.” Cultural Studies 21 (4-5): 718-737.

Maclure, Maggie. 2003. Discourse in Educational and Social Research. Maidenhead: Open University Press.

Mitchell, Kevin, Sally Marston, and Cindi Katz. 2004. Life's Work: Geographies of Social Reproduction. Oxford: Blackwell.

Moen, Phyliss, and Stephan Sweet. 2004. "From 'Work-Family' to 'Flexible Careers'." Community, Work \& Family 7 (2): 209-226.

Powell, Gary, and Kimberly Eddleston. 2013. "Linking Family-to-Business Enrichment and Support to Entrepreneurial Success: Do Female and Male Entrepreneurs Experience Different Outcomes?" Journal of Business Venturing 28 (2): 261-280. 
Powell, Gary, and Kimberly Eddleston. 2008. "The Paradox of the Contented Female Business Owner." Journal of Vocational Behaviour 73 (1): 24-36.

Presser, H. 2003. Working in a 24/7 Economy. New York: Russell Sage Foundation.

Rich, Adrienne. 1976. Of Woman Born: Motherhood as Experience and Institution. New York: W.W. Norton and Co.

Rothbard, Nancy, and Tracey Dumas. 2006. "Research Perspectives: Managing the WorkHome Interface.” In Work-Life Balance: A Psychological Perspective, edited by F. Jones, R Burke, and M. Westman. Hove and New York: Psychology Press, Taylor and Francis Group.

Stadlen, Naomi. 2004. What Mothers Do. London: Piatkus Limited.

Wiseman, June, Phillip Roe, and James Elliot. 2006. Annual Survey of Small Business UK 2004-2005. London: DTI. www.bis.gov.uk/files/file38251.pdf 